\title{
Invasive crayfish increase habitat connectivity: a case study in a large boreal lake
}

\author{
T.J. Ruokonen ${ }^{(1) \star}$, M. Kiljunen ${ }^{(1)}$, J. Karjalainen ${ }^{(1)}$, H. Hämäläinen ${ }^{(1)}$
}

Received October 9, 2012

Revised November 26, 2012

Accepted January 3, 2013

Key-words: crayfish, habitat connectivity, invasive species, stable isotopes

\section{ABSTRACT}

Several studies have shown that distinct compartments of lake ecosystems are coupled via transportation of organic matter, nutrients and energy across habitat boundaries. Here we evaluate the potential of the invasive signal crayfish (Pacifastacus leniusculus (Dana)) to modify energy pathways in large boreal lakes. Using a stable isotope mixing model and calculation of the isotopic niches we estimated the contribution of different food sources to the diets of crayfish captured from different habitats, and from that inferred their potential to transport energy across the littoralprofundal gradient. The crayfish caught from the littoral area utilized mainly littoral food sources, whereas the importance of profundal sources increased consistently with depth. We also found crayfish in deeper habitats with littoral $\delta^{13} \mathrm{C}$ label, which indicates significant use of littoral sources. These results presents evidence that invasive signal crayfish create a new link in energy transfer from littoral areas to profundal areas and thereby increase connectivity between these spatially distinct habitats. Our results highlight a need for better understanding of the role of crayfish in lake energy dynamics and habitat connectivity.

RÉSUMÉ

L'écrevisse invasive accroît la connectivité des habitats : une étude de cas dans un grand lac boréal

\section{Mots-clés :} écrevisses, connectivité des habitats, espèce envahissante, isotopes stables

\begin{abstract}
Plusieurs études ont montré que les différents compartiments des écosystèmes lacustres sont couplés via le transport de la matière organique, de nutriments et de l'énergie à travers les frontières de ces habitats. Ici, nous évaluons le potentiel de l'écrevisse signal invasive (Pacifastacus leniusculus (Dana)) à modifier les voies de l'énergie dans les grands lacs boréaux. En utilisant un modèle de mélange des isotopes stables et le calcul des niches isotopiques, nous avons estimé la contribution des différentes sources de nourriture pour l'alimentation des écrevisses capturées dans différents habitats, et déduit leur potentiel de transport d'énergie le long du gradient littoral-zone profonde. Les écrevisses capturées dans la zone littorale utilisent des sources alimentaires essentiellement littorales, alors que l'importance des sources de zone profonde augmente de façon régulière avec la profondeur. Nous avons aussi trouvé des écrevisses dans des habitats plus profonds avec une signature $\delta^{13} \mathrm{C}$ du littoral, ce qui indique une utilisation importante des sources
\end{abstract}

(1) Department of Biological and Environmental Science, University of Jyväskylä, Survontie 9, P.O. Box 35, 40014,

* Corresponding author: timo.j.ruokonen@jyu.fi 
littorales. Ces résultats présentent des preuves que l'écrevisse signal invasive crée un nouveau lien dans le transfert d'énergie à partir des zones littorales vers la zone profonde et donc augmente la connectivité entre ces habitats spatialement distincts. Nos résultats mettent en évidence la nécessité de mieux comprendre le rôle de l'écrevisse dans la dynamique de l'énergie d'un lac et la connectivité des habitats.

\section{INTRODUCTION}

The integration of spatially distinct habitats in lake ecosystems by movements of matter and energy across habitat boundaries is now well recognised. Several studies have shown that the contribution of benthic production can be important in whole lake energy dynamics (e.g. Vadeboncoeur et al., 2002; Schindler and Scheuerell, 2002) and that terrestrial subsidies can also be substantial (Jansson, 2007; Solomon et al., 2011). The role of mobile animals in the flow of organic matter and energy is indisputable in freshwater ecosystems (Covich et al., 1999; Schindler and Scheuerell, 2002). For instance, cross-habitat foraging of mobile predators is known to be an important pathway of energy transfer and one of the main factors connecting spatially distinct habitats in lakes (Vander Zanden and Vadeboncoeur, 2002; Dolson et al., 2009). Animals can also be important links in energy transfer between aquatic and terrestrial environments (Nakano and Murakami, 2001; Vander Zanden and Gratton, 2011). Changes in food web structure could lead to changes in energy flows, and in this context invasive fish species have been shown to change ecosystem processes and energy dynamics in lakes (Vander Zanden et al., 1999; Eby et al., 2006).

The North American signal crayfish (Pacifastacus leniusculus (Dana)) is spreading across Europe (Holdich et al., 2009) and is threatening the native biota (Westman et al., 2002; Stenroth and Nyström, 2003). Signal crayfish have been introduced to hundreds of lakes in southern Finland where they are replacing the indigenous noble crayfish (Astacus astacus L.) (Kirjavainen and Sipponen, 2004). The natural distribution of the native crayfish was confined mainly to rivers and the shallow littoral areas $(<3 \mathrm{~m})$ of small lakes (Westman et al., 2002), whereas signal crayfish also inhabit deeper sublittoral and profundal areas and have become particularly well established in large lakes (Erkamo et al., 2010). Previous investigations have indicated that signal crayfish use a wide range of littoral and profundal habitats in large lakes (Abrahamsson and Goldman, 1970; Flint, 1977) and in general crayfish can travel tens to hundreds of meters in $24 \mathrm{~h}$ (Byron and Wilson, 2001; Bubb et al., 2006). Therefore, introduced signal crayfish appear to represent a potential new link between spatially distinct littoral and profundal habitats in large boreal lakes. As the omnivorous crayfish are known to utilize a wide range of food sources from terrestrial plants to benthic macroinvertebrates (e.g. Stenroth et al., 2006; Grey and Jackson, 2012), they could also potentially increase connectivity between terrestrial and aquatic environments.

The aim of our study was to evaluate the potential of invasive crayfish to modify energy pathways in large boreal lakes by increasing habitat connectivity between littoral, profundal and terrestrial areas. We especially sought evidence as to whether (1) invasive signal crayfish create a new link in energy transfer between the productive shallow littoral and the less productive deep profundal areas, and (2) signal crayfish strengthen terrestrial-aquatic linkages. We approached these study questions by using stable isotope analysis (SIA) of carbon and nitrogen to estimate the contribution of littoral, profundal and terrestrial food sources to the diets of crayfish captured from different habitats. Based on previous findings (e.g. Syväranta et al. 2006, Solomon et al. 2011) we expected the isotope values of carbon and nitrogen to differ among the crayfish food sources of each habitat strongly enough to allow distinction of their contribution to the diet of crayfish. From this information, together with the width and position of the isotopic feeding niche among crayfish from different habitats, we inferred crayfish movements and transportation of organic matter and energy across the littoral-profundal gradient. 


\section{MATERIAL AND METHODS}

The study was conducted on 3rd to 6th of August in 2009 in Nyystölä Bay of Lake Päijänne (Finland, $61^{\circ} 33^{\prime} \mathrm{N} 25^{\circ} 35^{\prime} \mathrm{E}$ ). The lake has a total area of $1118 \mathrm{~km}^{2}$ and the surface area of Nyystölä Bay is $7 \mathrm{~km}^{2}$ with a maximum depth of $30 \mathrm{~m}$. The area is classified as oligotrophic with average total phosphorus $6.6 \mu \mathrm{g} \cdot \mathrm{L}^{-1}$ and Secchi depth of $4.5 \mathrm{~m}$. According to Finnish Game and Fisheries Research Institute crayfish introduction register signal crayfish introductions to the study area started in the early 1990s and the crayfish are now abundant all over the bay area.

\section{STABLE ISOTOPE ANALYSIS AND SAMPLE COLLECTION}

Analysis of carbon and nitrogen stable isotopes is a widely used method to evaluate the structure and function of food webs (e.g. Fry, 2006, Layman et al. 2012). The ratio of carbon isotopes $\left({ }^{13} \mathrm{C}\right.$ to $\left.{ }^{14} \mathrm{C}\right)$ can be used to trace the consumer food sources since it changes little once transferred thorough food webs (e.g. Peterson and Fry, 1987). Instead, the ratio of nitrogen isotopes $\left({ }^{15} \mathrm{~N}\right.$ to $\left.{ }^{14} \mathrm{~N}\right)$ can be used to estimate consumer trophic position because nitrogen enriches in predictable way between trophic levels (e.g. Peterson and Fry, 1987). We measured carbon and nitrogen stable isotope ratios of crayfish and of potential food sources. All samples for isotope analysis were freeze dried to constant weight and ground to a fine homogenous powder. Samples were then weighed $(0.5-0.7 \mathrm{mg})$ into tin caps and encapsulated. Analyses of carbon and nitrogen stable isotopes were made with a FlashEA1112 elemental analyzer coupled to a Thermo Finnigan DELTAplus Advantage continuous flow isotope ratio mass spectrometer (Thermo Electron Corporation, Waltham, MA, USA). The reference materials used were internal standards of known relation to the international standards of Vienna Pee Dee belemnite for carbon isotopes and atmospheric nitrogen for nitrogen isotopes. White muscle tissue of pike (Esox lucius L.) and potato leaves (Solanum tuberosum L.) with known isotopic compositions were used as internal working standards to ensure the precision of analyses. One standard sample was run repeatedly after every six samples in each sequence. Results are expressed using the conventional $\delta$ notation as parts per thousand difference from the international standards (e.g. Fry 2006). Standard deviations within reference samples in each sequence were less than $0.08 \%$ for carbon and $0.15 \%$ o for nitrogen in pike samples and less than $0.08 \%$ o for carbon and $0.19 \%$ o for nitrogen in potato leaf samples.

Crayfish for the analysis were collected by trapping across the gradient from littoral to profundal areas, divided into four depth zones in stony shores with only sparse vegetation. The depth zone from the shoreline to three meters represents the productive, well illuminated, littoral habitat with stony bottom. The depth from three to six meters roughly represents the sublittoral transition zone (gravel, some stones) between littoral and deep profundal. The zones from six to nine meters and nine to $20 \mathrm{~m}$ both represent soft bottom, deep water, profundal habitat (fine gravel, mud, silt). We set traps (mesh size $15 \mathrm{~mm}$ ) baited with fresh fish flesh in transects perpendicular to the shore line and extending from the depth of $0.5 \mathrm{~m}$ to $15-20 \mathrm{~m}$. Each line consisted of 25 traps at five meter intervals (total length $125 \mathrm{~m}$ ) to prevent overlap of effective trapping area (Abrahamsson and Goldman, 1970). Traps were set at five different locations around the bay in the evening and retrieved the following morning. Depth zones were measured during trap setting using a plumb line or an echo-sounder. Twenty crayfish (males and females equally) for SIA were randomly collected from each depth zone around the bay during trap retrieval. Crayfish were immediately killed and frozen. In the laboratory, crayfish carapace lengths were measured and a piece of abdominal muscle tissue from each crayfish was dissected for SIA. Untreated muscle tissue was used to measure the stable isotope ratios as recommended by Stenroth et al. (2006).

We collected potential crayfish prey items from littoral, profundal and terrestrial area for SIA to represent a general isotopic baseline of each habitat (Table I). Samples were collected from two sites at opposite sides of the study bay to cover possible spatial variation in stable isotope values (Syväranta et al., 2006). As no major differences were found between 


\section{Table I}

Summary of stable isotope ratios and additional information of organisms investigated in Nyystölä Bay. Mean values (SD) of signal crayfish used in SIAR-model.

\begin{tabular}{|l|c|c|c|c|c|c|}
\cline { 2 - 6 } \multicolumn{1}{c|}{} & Habitat & $n$ & $\delta^{13} \mathrm{C}(\%)$ & $\delta^{15} \mathrm{~N}(\% \circ)$ & C:N & Length (mm) \\
\hline Crayfish & & & & & & \\
0-3 $\mathbf{~ m}$ & Littoral & 20 & $-19.4(1.6)$ & $9.2(0.6)$ & $3.2(0.1)$ & $46.6(8.7)$ \\
3-6 $\mathbf{~ m}$ & Sub-littoral & 20 & $-20.9(2.2)$ & $9.8(0.7)$ & $3.3(0.1)$ & $48.1(10.7)$ \\
$\mathbf{6 - 9} \mathbf{~ m}$ & Profundal & 20 & $-22.8(2.3)$ & $10.5(0.8)$ & $3.2(0.1)$ & $49.1(5.6)$ \\
$>\mathbf{9} \mathbf{~ m}$ & Profundal & 20 & $-22.5(2.5)$ & $10.6(1.0)$ & $3.2(0.1)$ & $49.4(6.3)$ \\
\hline
\end{tabular}

Mean values (SD) for taxa and pooled groups used as littoral, profundal and terrestrial baselines in SIARmodel. $n=$ number of analysed samples, some samples comprised 2 individuals to reach sufficient amount material for analysis.

\begin{tabular}{|c|c|c|c|c|c|c|}
\hline Food source & Site & Habitat & $n$ & $\delta^{13} \mathrm{C}(\%)$ & $\delta^{15} \mathrm{~N}(\% \circ)$ & $\mathrm{C}: \mathrm{N}$ \\
\hline \multirow[t]{2}{*}{ Asellus aquaticus } & 1 & Littoral & 1 & -16.1 & 4.9 & 6.5 \\
\hline & 2 & & 2 & $-16.4(0.6)$ & $4.4(0.1)$ & $5.5(0.8)$ \\
\hline \multirow[t]{2}{*}{ Bithynia tentaculata } & 1 & Littoral & 4 & $-19.0(1.3)$ & $3.3(0.2)$ & $4.7(0.2)$ \\
\hline & 2 & & 3 & $-20.2(0.8)$ & $3.9(0.5)$ & $4.9(0.5)$ \\
\hline Gyraulus sp. & 1 & Littoral & 4 & $-20.2(0.8)$ & $4.2(0.3)$ & $4.0(0.1)$ \\
\hline Heptagenia dalecarlica & 2 & Littoral & 3 & $-21.4(1.5)$ & $5.4(1.1)$ & $4.7(0.2)$ \\
\hline Leuctra fusca & 2 & Littoral & 2 & $-19.6(2.0)$ & $5.4(0.8)$ & $5.4(0.2)$ \\
\hline \multirow[t]{2}{*}{ Polycentropus flavomaculatus } & 1 & Littoral & 4 & $-18.8(0.9)$ & $6.0(0.6)$ & $4.2(0.4)$ \\
\hline & 2 & & 3 & $-18.0(2.3)$ & $5.3(0.3)$ & $4.3(0.4)$ \\
\hline \multirow[t]{2}{*}{ Periphyton } & 1 & Littoral & 3 & $-13.5(2.2)$ & $2.1(0.8)$ & $7.3(0.3)$ \\
\hline & 2 & & 3 & $-14.2(2.0)$ & $1.4(0.9)$ & $7.6(0.2)$ \\
\hline Littoral baseline & & & pooled & $-18.4 \pm 2.7$ & $4.4(1.3)$ & \\
\hline \multirow[t]{2}{*}{ Sphaerium sp. } & 1 & Profundal & 4 & $-26.5(1.8)$ & $4.3(0.7)$ & $4.6(0.6)$ \\
\hline & 2 & & 3 & $-27.2(1.9)$ & $4.0(0.3)$ & $4.2(0.2)$ \\
\hline \multirow[t]{2}{*}{ Oligochaeta spp. } & 1 & Profundal & 3 & $-26.8(1.1)$ & $9.3(0.1)$ & $4.5(0.2)$ \\
\hline & 2 & & 2 & $-25.2(0.1)$ & $9.7(0.4)$ & $4.5(0.1)$ \\
\hline \multirow[t]{2}{*}{ Chironominae sp. } & 1 & Profundal & 1 & -28.8 & 9.4 & 4.9 \\
\hline & 2 & & 2 & $-25.7(0.4)$ & $11.1(0.2)$ & $4.6(0.3)$ \\
\hline \multirow[t]{2}{*}{ Procladius sp. } & 1 & Profundal & 4 & $-28.8(0.4)$ & $7.4(1.4)$ & $4.2(0.2)$ \\
\hline & 2 & & 3 & $-28.0(0.4)$ & $6.5(0.5)$ & $4.3(0.3)$ \\
\hline Mysis relicta & 1 & Profundal & 1 & -28.4 & 8.5 & 3.7 \\
\hline \multirow[t]{2}{*}{ Monoporeia affinis } & 1 & Profundal & 3 & $-35.1(1.1)$ & $6.9(0.2)$ & $9.0(1.6)$ \\
\hline & 2 & & 1 & -32.0 & 8.5 & 7.2 \\
\hline \multirow[t]{2}{*}{ Sediment } & 1 & Profundal & 1 & -26.6 & 4.4 & 6.3 \\
\hline & 2 & & 1 & -26.3 & 3.3 & 6.4 \\
\hline \multirow[t]{2}{*}{ Zooplankton } & 1 & Profundal & 2 & $-28.7(0.1)$ & $4.4(0.1)$ & $4.6(0.1)$ \\
\hline & 2 & & 2 & $-28.7(0.1)$ & $4.2(0.1)$ & $4.6(0.1)$ \\
\hline Profundal baseline & & & pooled & $-28.2(2.7)$ & $6.9(2.6)$ & \\
\hline \multirow[t]{2}{*}{ Alnus glutinosa } & 1 & Terrestrial & 3 & $-28.1(0.1)$ & $-2.4(0.1)$ & $18.8(1.7)$ \\
\hline & 2 & & 3 & $-27.8(0.6)$ & $-2.4(0.2)$ & $20.5(3.9)$ \\
\hline \multirow[t]{2}{*}{ Betula pendula } & 1 & Terrestrial & 2 & $-29.2(0.1)$ & $-3.1(1.5)$ & $56.3(16.4)$ \\
\hline & 2 & & 2 & $-29.1(0.8)$ & $-2.7(1.3)$ & $35.3(23.4)$ \\
\hline Terrestrial baseline & & & pooled & $-28.5(0.8)$ & $-2.6(0.8)$ & \\
\hline
\end{tabular}




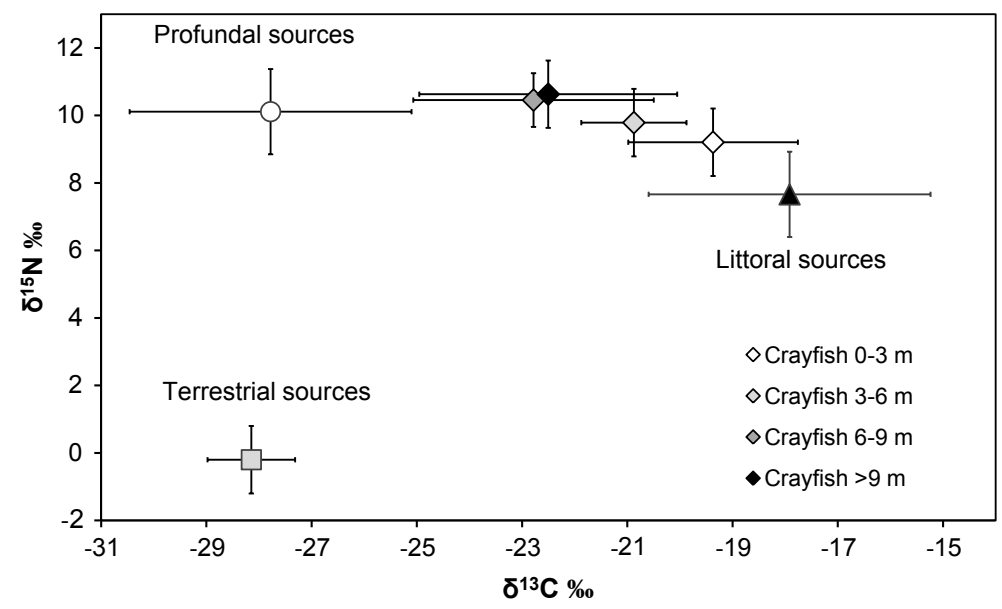

\section{Figure 1}

Bi-plot of mean $\delta^{13} \mathrm{C}$ and $\delta^{15} \mathrm{~N}$ values $( \pm S D)$ for crayfish captured from different depths and for littoral, profundal and terrestrial food sources (corrected for trophic enrichment) used in stable isotope mixing model (SIAR) in the Nyystölä Bay.

sites (Table I), samples from each habitat were pooled for baseline calculations. Littoral food sources included the most abundant macroinvertebrates (Asellus aquaticus, Bithynia tentaculata, Gyraulus sp., Heptagenia dalecarlica, Leuctra fusca, Polycentropus flavomaculatus) which were collected using a hand net and periphyton which was brushed from stone surfaces. Profundal food sources were collected at the open water area (depth $\sim 10 \mathrm{~m}$ ) near the crayfish sampling sites, and included the surface sediment layer collected using a Kajak-corer and the most abundant macroinvertebrates (Sphaerium sp., Chironomidae spp., Mysis relicta, Monoporeia affinis) collected using an Ekman-grab. The whole body of macroinvertebrates was used for SIA, except snails and mussels, for which only the soft body tissue was used. We also included pelagic zooplankton in profundal sources, as sedimented pelagic material underpins much profundal production. Bulk zooplankton samples were collected by vertical net pulls (mesh size $150 \mu \mathrm{m}$ ) from bottom to surface. Fallen leaves of deciduous trees (Betula pedula L., Alnus glutinosa L.) were collected from the shoreline to represent the terrestrial food source.

\section{CONTRIBUTION OF LITTORAL, PELAGIC AND TERRESTRIAL FOOD SOURCES}

We used the SIAR-package (Parnell et al., 2010) in R (R Development Core Team, 2009) to create a three source mixing model to estimate the proportion of different food sources used by signal crayfish in different habitats. The mean values and standard deviations of isotopic values of pooled littoral, profundal and terrestrial food sources were used in the model as sources (Figure 1; Table I). As no crayfish-specific trophic fractionation corrections were available, we used values from the literature. For animal food we used correction values of $3.23 \%$ o \pm 0.41 for $\delta^{15} \mathrm{~N}$ and $0.47 \%$ o \pm 1.23 for $\delta^{13} \mathrm{C}$ (Vander Zanden and Rasmussen, 2001), and values of $2.4 \% \circ \pm 0.42$ and $0.40 \% \pm \pm 0.28$, respectively for plants and periphyton (McCutchan et al., 2003). We added concentration corrections (C and $\mathrm{N}$ percentages obtained during SIA, mean calculated for each source) into the model to account for the varying assimilation of carbon and nitrogen from different food sources (Parnell et al., 2010). We present outputs from the mixing model as mean proportions with 95\% Bayesian credibility intervals. 


\section{TROPHIC POSITION ESTIMATION AND TROPHIC NICHE WIDTH}

Consumers in lakes can utilize food sources from more than one basal source (e.g. from littoral and pelagic food webs) which can cause spatial heterogeneity in nitrogen values (Post, 2002). Our three-source mixing model outputs indicated that the proportion of terrestrial food sources in crayfish diets was minor and therefore we estimated the trophic position (TP) of each crayfish using a two-source trophic position model for further calculations (Post, 2002):

$$
\text { TP }=\lambda+\left(\delta^{15} \mathrm{~N}_{\text {crayfish }}-\left[\delta^{15} \mathrm{~N}_{\text {littoral }} \times \alpha+\delta^{15} \mathrm{~N}_{\text {pelagic }} \times(1-\alpha)\right]\right) / \Delta^{15} \mathrm{~N}
$$

where $\lambda$ is the trophic position of the organisms used to estimate $\delta^{15} N_{\text {littoral }}$ of and $\delta^{15} N_{\text {pelagic }}$ (in this case $\lambda=2$ for primary consumers), $\delta^{15} N_{\text {crayfish }}$ is measured directly from individual crayfish, and $\Delta^{15} \mathrm{~N}$ is enrichment of $\delta^{15} \mathrm{~N}$ for one trophic level, which was assigned to be 3.23, based on fish values reviewed by Vander Zanden and Rasmussen (2001). $\delta^{15} \mathrm{~N}_{\text {littoral }}$ and $\delta^{15} \mathrm{~N}_{\text {pelagic }}$ were assigned based on respective mean values of gastropod snail (Bithynia tentaculata) samples collected from the littoral and bivalve mollusc (Sphaerium sp.) samples representing the values of pelagic area. $\alpha$ is the proportion of nitrogen in signal crayfish individuals derived from the base of the littoral food web, estimated using the carbon isotope values in a two-end-member-mixing model:

$$
\alpha=\left(\delta^{13} \mathrm{C}_{\text {crayfish }}-\delta^{13} \mathrm{C}_{\text {pelagic }}\right) /\left(\delta^{13} \mathrm{C}_{\text {littoral }}-\delta^{13} \mathrm{C}_{\text {pelagic }}\right)
$$

which allows for the differentiation between two sources, such as the littoral and pelagic food webs found in lakes (Post, 2002).

Quantification (total area and variability) of consumer isotopic niche in $\delta^{13} \mathrm{C}-\delta^{15} \mathrm{~N}$ space to represent trophic niche characteristics has recently been used to explore resource use and niche partitioning in community and population level studies (e.g. Layman et al., 2007; Ruokonen et al., 2012). We measured isotopic feeding niches for signal crayfish captured from different depths to estimate the subpopulation partitioning of resource use and main foraging areas. We determined feeding niches as standard ellipse areas (SEA) from crayfish location in trophic position (TP) and $\delta^{13} \mathrm{C}$ space using SIBER (Stable Isotope Bayesian Ellipses in R) package (Jackson et al., 2011). These standard ellipses represent core isotopic niche area defining typical resource use in each population (Jackson et al., 2011).

\section{STATISTICAL ANALYSIS}

We tested differences in crayfish stable isotope ratios and trophic position among depth zones using ANCOVA with isotope ratios $\left(\delta^{13} \mathrm{C}, \delta^{15} \mathrm{~N}\right)$ and trophic position estimates (TP) as the dependent values, depth zone as fixed factor and length of crayfish as the covariate. If differences were found among depths, analysis continued with Bonferroni's pair-wise comparisons. Stable isotope ratios and TP were not different between crayfish sexes and were left out from the analysis to meet normality and variance homogeneity assumptions. Differences in crayfish length among depth zones and between sexes were tested using 2-way ANOVA (length as dependent value, depth zone and sex as fixed factors). We tested data for normality using the Kolmogorov-Smirnov test and for homogeneity of variances using Levene's test. If normality or homogeneity assumptions were not met, data were log-transformed. We performed statistical tests with SPSS version 15.0 (SPSS Inc., Chicago, IL, USA).

\section{RESULTS}

The mean isotope values and trophic position of signal crayfish showed consistent differences among the habitats (Figure 1). Mean $\delta^{13} \mathrm{C}$ values differed among the depths (ANCOVA: $F=$ 9.97, d.f. $=3, P<0.001$ ), being significantly higher in crayfish from the littoral area than in 


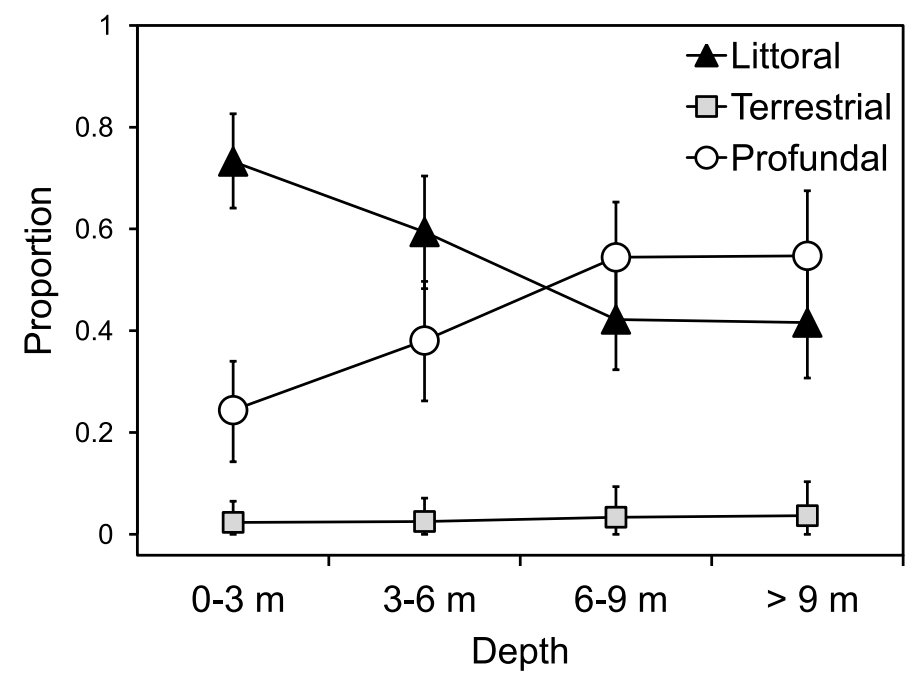

\section{Figure 2}

Proportions of food sources in the signal crayfish diet in different depth zones, as predicted from the stable isotope mixing model (SIAR). Error bars represent 95\% Bayesian credibility intervals.

crayfish captured from the profundal area (0-3 $\mathrm{m}$ vs. 6-9 $\mathrm{m} P<0.001 ; 0-3 \mathrm{~m}$ vs. $>9 \mathrm{~m}$ $P<0.001)$. Length of crayfish did not affect $\delta^{13} \mathrm{C}$ values $(F=1.17, d . f .=1, P=0.282)$.

Crayfish mean $\delta^{15} \mathrm{~N}$ values also differed among depths (ANCOVA: $F=12.83$, d.f. $=3, P<$ $0.001)$, and increased with length $(P=0.017)$. In the littoral area, $\delta^{15} \mathrm{~N}$ values were significantly lower than in the profundal area $(P<0.001)$ but there was no difference between the two shallowest habitats (0-3 m vs. 3-6 $\mathrm{m} P=0.104)$. Crayfish caught from the sublittoral had lower $\delta^{15} \mathrm{~N}$ values than crayfish from the deepest zone $(P=0.011)$ but no difference between crayfish from sublittoral and 6-9 m profundal zone $(P=0.060)$.

Mean trophic position of crayfish differed significantly between habitats (ANCOVA: $F=11.09$, d.f. $=3, P<0.001$ ). On average, crayfish caught from the profundal occupied a somewhat higher trophic position (mean 4.02 and 4.08) than crayfish captured from the littoral (mean 3.74) and sublittoral (mean 3.87) areas. Length of crayfish had a significant effect on trophic position $(P=0.013)$. Overall, mean carapace length of crayfish was consistent between the habitats (2-way ANOVA: $F=0.92$, d.f. $=3, P=0.438$ ), but males (mean $50 \mathrm{~mm}$ ) were significantly longer than females (mean $46 \mathrm{~mm}$ ) (2-way ANOVA: $F=7.13$, d.f. $=1$, $P=0.009)$. Analysis did not reveal 242 any interaction between habitat and sex $(F=1.97$, $P=0.126)$.

The mixing model outputs indicated that the mean contribution of food sources in crayfish diets at the population level differed between littoral and profundal areas (Figure 2). Crayfish caught from the littoral mainly used food which originated from the littoral food web, accounting for between $64 \%$ and $83 \%$ of diet $(95 \% \mathrm{Cl})$. Crayfish from the sublittoral also relied mostly on littoral food sources $(48-70 \%)(95 \% \mathrm{Cl})$, but the contribution of profundal sources was slightly higher compared with littoral crayfish (Figure 2). The proportion of profundal sources increased progressively with depth and crayfish caught from the two deep water areas used more profundal food sources (44-65\% and 44-68\%) (95\% Cl) than littoral sources. However, the predicted contribution of littoral food sources to crayfish diets was still important varying from $32 \%$ to $52 \%$ and from $31 \%$ to $52 \%$ in the two deepest areas, respectively (Figure 2). The estimated proportion of terrestrial sources was very low in all habitats representing only $0 \%$ to $9 \%(95 \% \mathrm{Cl})$ of the diet (Figure 2).

We observed clear and consistent differences in crayfish feeding niches among the different habitats. Crayfish captured from the littoral had the smallest standard ellipse area (SEA = $0.75)$, the placement of which in trophic position and $\delta^{13} \mathrm{C}$ space indicates that most crayfish there mainly utilized littoral food sources (Figure 3). The variation in $\delta^{13} \mathrm{C}$ values among individuals increased consistently with depth and crayfish caught from deeper water zones 


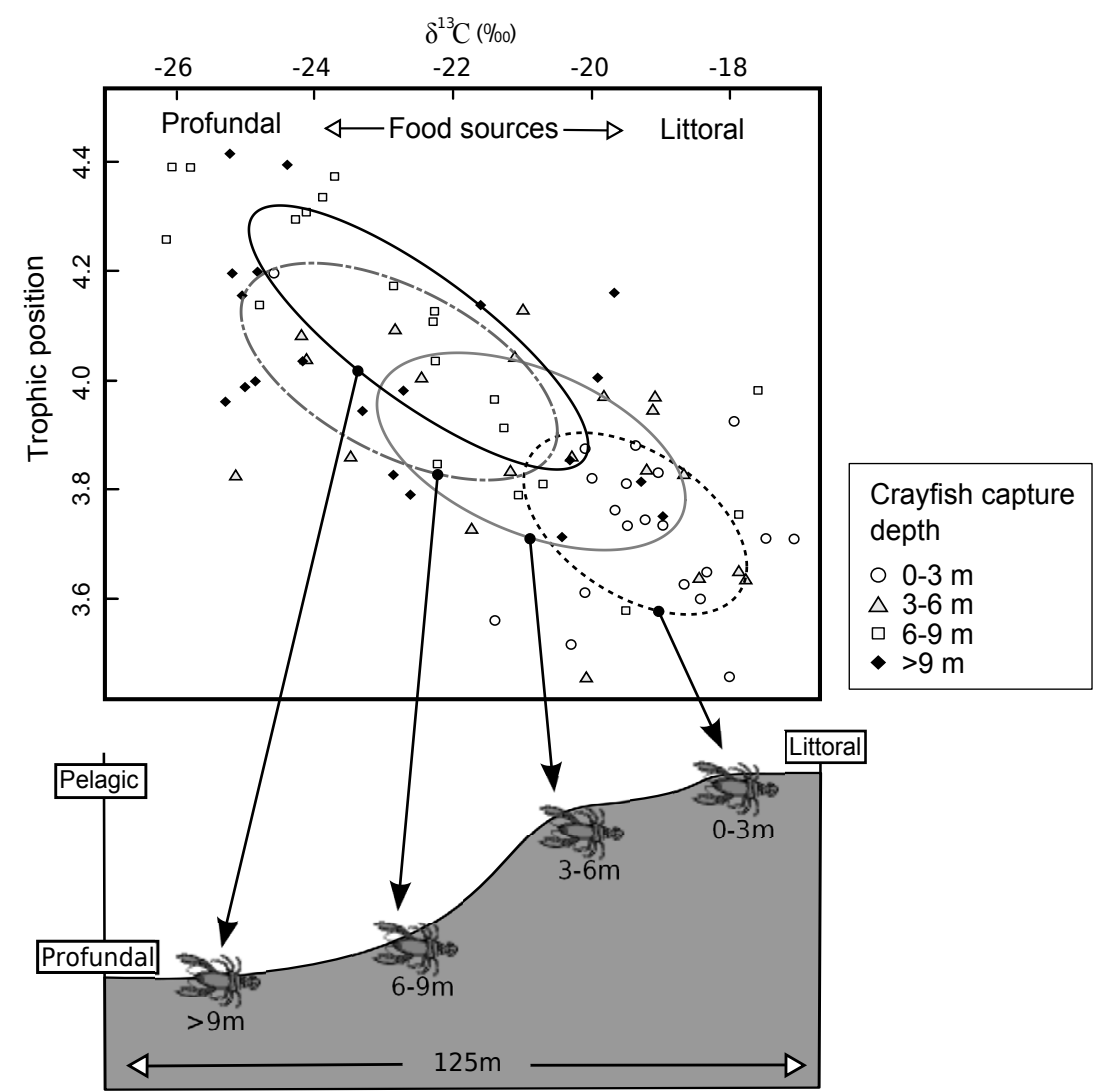

Figure 3

The feeding niche breadth (standard ellipse area) of signal crayfish captured from different depth zones in Nyystölä Bay. Each marker indicates the location of an individual crayfish in the trophic position and $\delta^{13} \mathrm{C}$ space, and each depth zone is depicted with a different symbol: white circles $=0-3 \mathrm{~m}$, white triangles $=3-6 \mathrm{~m}$, black diamonds $=6-9 \mathrm{~m}$, white squares $=>9 \mathrm{~m}$.

had broader feeding niches (SEAs: $3-6 \mathrm{~m}=1.11,6-9 \mathrm{~m}=1.19,>9 \mathrm{~m}=1.08$ ) compared to littoral crayfish (Figure 3).

\section{DISCUSSION}

We found clear differences in stable isotope values, trophic position, food source utilization and feeding niches among signal crayfish captured from different habitats. On the basis of outputs from a mixing model, crayfish caught from the shallow littoral mainly utilized littoral food sources, whereas the importance of profundal food sources in crayfish diets increased progressively with depth of capture. We actually found crayfish individuals with higher $\delta^{13} \mathrm{C}$ values, similar to those of littoral food sources, all over the lake bottom, and we infer that this indicates significant use of littoral food sources by some crayfish found in deeper habitats. That supports our first hypothesis that invasive signal crayfish create a new link in energy transfer from productive shallow littoral to less productive deep water profundal areas and thereby might even significantly subsidize deep water areas with littoral energy. In contrast, crayfish with carbon signatures overlapping with profundal food source signatures were virtually lacking from the littoral area. This pattern indicates that the prevailing direction of energy transfer is from littoral to profundal.

The use of stable isotopes as intrinsic biochemical markers is considered an effective technique for providing information about feeding location of animals because their tissues reflect the isotope values of their food (e.g. Rubenstein and Hobson, 2004). When there exist clear 
distinctions in isotope values (e.g. $\delta^{13} \mathrm{C}$ ) among food sources in different habitats or geographical areas, this information can be used to track population-level movements (e.g. Hobson et al., 2003) and energy pathways across habitats (Peterson and Fry, 1987; Vander Zanden et al., 2006). Unlike conventional techniques, measurements of stable isotopes provide time-integrated information about animal movements (Rubenstein and Hobson, 2004). Studies on isotopic turnover in ectotherms, and particularly in crustaceans, indicate that crayfish tail muscle tissue (used in this study) has a slow isotopic turnover rate (Suring and Wing, 2009), and therefore provides a long-term indicator of movement patterns during the summer season. As crayfish are poikilothermic animals, their activity and consumption rate will peak during the warm water period in summer. Therefore our study, conducted in late summer, probably reflected the most extreme situation with respect to movements and the greatest influence on trophic dynamics. Although there may be some seasonal variation in stable isotope values of basal food sources (e.g. Post, 2002), we can presume that there was nevertheless a clear distinction between sources through the ice-free season (Syväranta et al., 2006) and that our results can thus be generalized for the whole warm water summer period.

The magnitude and significance of energy transfer depends on the abundance of crayfish and on their movement and migration patterns, which we cannot obtain from stable isotope data alone. Hence there appear to be two alternative possible explanations for our observed depth distributions of crayfish stable isotope values and inferred diets. According to previous studies, crayfish show both short-term diel and long-term seasonal movements (Abrahamson and Goldman, 1970; Flint, 1977; Bubb et al., 2006). Crayfish are capable of moving long distances in a short time, travelling tens to hundreds of meters per day (Flint, 1977; Byron and Wilson, 2001; Bubb et al., 2006). Short-term movements are mainly suggested to be related to foraging and predatory avoidance (Momot and Gowan, 1972; Flint, 1977; Byron and Wilson, 2001). In our study, crayfish samples were collected rather close to the lake shore, the maximum distance being $125 \mathrm{~m}$. Therefore we suggest that signal crayfish in our study area are able to move between littoral and profundal area on a daily basis. Hence, crayfish caught from the profundal area but exhibiting a markedly littoral isotope signal might be 'daily commuters', foraging mainly in the more productive littoral area and spending other times in the deep water area.

However, as stable isotope signatures reflect longer-term diet, there is also the possibility that these crayfish might have relocated to the profundal area some time earlier but their tail tissue still reflects the littoral isotope signal. Long-term movements of crayfish are presumably related to larger scale phenomena like seasonal shifts in weather conditions (Abrahamsson and Goldman, 1970; Flint, 1977). Signal crayfish are known to migrate to deeper areas during fall to avoid harsh winter conditions in the shallow littoral area (Abrahamsson and Goldman, 1970) and females are also supposed to migrate during the reproductive season to find better incubation conditions for eggs (Momot and Growing, 1972). Movements related to short-term foraging and long-term seasonal habitat shifts are likely to be bidirectional and follow rather well defined patterns. However, movements could also be definitive, so that animals leaving an area will not return. Those kinds of movements, especially in invasive species, might be related to range expansion (Davis, 2010). In our study area, crayfish densities are high, especially in the littoral and sublittoral areas, so that one explanation for deep water foraging or settlement might be strong competition for resources in the littoral area. Resource competition could thus also partly explain the occurrence of crayfish with littoral isotope signals in deep water area.

Crayfish have been reported to utilize terrestrial detritus (e.g. leaf litter) as one of their main food sources in streams, small lakes and ponds (Usio, 2000; Montemarano et al., 2007) and hence to play an important role in detritus breakdown (Usio, 2000; Schofield et al., 2001) and in flow of allochthonous material and energy between terrestrial and aquatic habitats (Larson et al., 2011). However, our mixing model outputs suggest that the proportion of terrestrial food sources in the crayfish diets was very low at all depths. This indicates that signal crayfish are not extensively using terrestrial leaf litter sources during the summer season in our study area, and we can therefore infer that in large lakes signal crayfish do not substantially link terrestrial 
and aquatic habitats by direct feeding on terrestrial detritus. The importance of terrestrial subsidies to lakes is dependent on lake-specific properties (e.g. surface and watershed area) (Babler et al., 2011; Francis et al., 2011), and we suggest that the most likely reason for the minor consumption of terrestrial material is simply its low overall availability. In large lakes, the ratio between shoreline edge area and total surface area is generally low which leads to a low total input of terrestrial leaf litter (Gasith and Hasler, 1976). However, in northern latitudes leaf litter availability is strongly seasonal, with the vast majority of input in fall. During that period terrestrial sources might be more important in the diets of crayfish and hence their importance in habitat coupling higher, even though overall consumption by crayfish is then presumably rather low because of reduced activity during the cooler water season (Flint, 1977).

Our observations indicate that part of the crayfish captured from the deep water area used extensively profundal food sources originating from the phytoplankton-driven pelagic food web. This suggests that some crayfish live there rather permanently or at least mainly forage in deep water area. Crayfish population in the study area might be divided into distinct subpopulations as evidenced by the low overlap in isotopic niches among crayfish captured from littoral and profundal area. These results underpins the finding of Quevedo et al. (2009) that this kind of intrapopulation niche partitioning could limit the ability of individual animals to link spatially distinct food chains and decouple cross-habitat linkages. In any case, the spread of signal crayfish to profundal habitats introduces a new functional group into deep water areas of Finnish lakes since the spatial distribution of indigenous noble crayfish is confined strictly to shallow stony littoral areas (Westman et al., 2002). In general, macroinvertebrates have an important role in energy and nutrient cycling in freshwater ecosystems (Covich et al., 1999). For example, migration of these animals between benthic and pelagic habitats and the physical perturbation of substrates could enhance benthic-pelagic linkage via increase in nutrient release (Vanni, 2002; Weidman et al., 2011). We suggest that expansion of this largebodied invader to the deep water areas potentially alters in several ways these habitats where physical conditions are presumably rather stable and natural perturbation is low (Stendera and Johnson, 2008). First, signal crayfish can alter benthic invertebrate community composition by direct predation, as documented for littoral habitats in several studies (e.g. Dorn and Wojdak, 2004; McCarthy et al., 2006). Second, crayfish can enhance nutrient recycling and translocation via excretion and egestion. As omnivores, crayfish are able to consume various food sources (e.g. macrophytes, invertebrates, fish carcasses, organic sediment layer) and then release nutrients in forms that can be used more easily by primary producers (Vanni, 2002). Third, crayfish can cause mechanical perturbation by walking or by burrowing activities which can affect nutrient exchange between sediment and overlying water (Rodriguez et al., 2005).

The importance of fish in habitat coupling and energy transportation between littoral and pelagic/profundal in lakes has been acknowledged in previous studies (Schindler and Scheuerell, 2002; Vander Zanden and Vadeboncoeur, 2002; Dolson et al., 2009), but other animal groups have not received much attention. To our knowledge, our study conducted in real ecosystem, presents the first empirical evidence that invasive crayfish can create a new route in energy transfer from littoral to profundal areas and thereby increase connectivity between these spatially distinct habitats in large lakes. In future, studies combining accurate estimation of crayfish movement patterns and modelling of energy fluxes across habitats are needed to clarify the role of crayfish, both native and non-native, in lake energy dynamics and habitat connectivity.

\section{ACKNOWLEDGEMENTS}

Simo Jalli, Ilari Vaahto and Antti Martikainen assisted with the field work. We thank Prof. Roger Jones for the linguistic help and for useful comments. The study was funded by the Maj and Tor Nessling Foundation and by the Crayfish Research Program of the Finnish Game and Fisheries Institute. 


\section{REFERENCES}

Abrahamsson S. and Goldman C.R., 1970. Distribution, density and production of the crayfish, Pacifastacus leniusculus Dana in Lake Tahoe, California - Nevada. Oikos. 21, 83-91.

Babler A.L., Pilati A. and Vanni M.J., 2011. Terrestrial support of detrivorous fish populations decreases with watershed size. Ecosphere, 2, art76.

Bubb D. Thom T.T. and Lucas M.C., 2006. Movement patterns of the invasive signal crayfish determined by PIT telemetry. Can. J. Zool., 84, 1202-1209.

Byron C.J. and Wilson K.A., 2001. Rusty crayfish (Orconectes rusticus) movement within and between habitats in Trout Lake, Vilas County, Wisconsin. J. N. Am. Benthol. Soc., 20, 606-614.

Covich A.P., Palmer M.A. and Crowl T.A., 1999. The role of benthic invertebrate species in freshwater ecosystems. Bioscience, 46, 119-126.

Davis M.A., 2010. Invasion Biology. Oxford University Press, New York, p. 244.

Dolson R, McCann K., Rooney N. and Ridgway M., 2009. Lake morphometry predicts the degree of habitat coupling by a mobile predator. Oikos, 118, 1230-1238.

Dorn N.J. and Wojdak J.M., 2004. The role of omnivorous crayfish in littoral communities. Oecologia, 140, 150-159.

Eby L.A., Roach W.J., Crowder L.B. and Stanford J.A., 2006. Effects of stocking-up freshwater food webs. Trends Ecol. Evol., 21, 576-584.

Erkamo E., Ruokonen T, Alapassi T., Ruokolainen J., Järvenpää T., Tulonen J. and Kirjavainen J., 2010. Evaluation of crayfish stocking success in Finland. Freshwater Crayfish, 17, 77-83.

Flint W., 1977. Seasonal activity, migration and distribution of the crayfish, Pacifastacus leniusculus, in Lake Tahoe. Am. Mid. Nat., 97, 208-292.

Francis T.B., Schindler D.E., Holtgrieve G.W., Larson E.R., Scheuerell M.D., Semmens B.X. and Ward E.J., 2011. Habitat structure determines resource use by zooplankton in temperate lakes. Ecol. Lett. 14, 364-372.

Fry B., 2006. Stable isotope ecology. Springer Science and Business Media, New York, p. 308.

Gasith A. and Hasler A.D., 1976. Airborne litterfall as a source of organic matter in lakes. Limnol. Oceanog., 21, 253-258.

Grey J. and Jackson M., 2012. 'Leaves and shoots': Direct terrestrial feeding can supplement invasive red swamp crayfish in times of need. PLOS ONE, 7, e42575.

Hobson K.A., Wassenaar L.I, Mila B., Lovette I., Dingle C. and Smith T.B., 2003. Stable isotopes as indicators of altitudinal distributions and movements of an Ecuadorean hummingbird community. Oecologia, 136, 302-308.

Holdich D.M., Reynolds J.D., Souty-Grosset C. and Sibley P.J., 2009. A review of the ever increasing threat to European crayfish from non-indigenous crayfish species. Knowl. Managt. Aquatic Ecosyst., 11, 394-395.

Jackson A.L., Inger R., Parnell A.C. and Bearhop S., 2011. Comparing isotopic niche widths amog and within communities: SIBER - Stable Isotope Bayesian Ellipses in R. J. Anim. Ecol., 8, 595-602.

Jansson M., Persson L., De Roos A.M., Jones R.I. and Tranvik L.J., 2007. Terrestrial carbon and intraspecific size variation shape lake ecosystems. Trends Ecol. Evol., 22, 316-322.

Kirjavainen J. and Sipponen M., 2004. Environmental benefit of different crayfish management strategies in Finland. Fish. Manag. Ecol., 11, 213-218.

Larson E.R., Olden J.D. and Usio N., 2011. Shoreline urbanization interrupts allochthonous subsidies to a benthic consumer over a gradient of lake size. Biol. Lett., doi: 10.1098/rsbl.2011.0089.

Layman C.A., Arrington D.A., Montana C.G. and Post D.M., 2007. Can stable isotope ratios provide for community-wide measures of trophic structure? Ecology, 88, 42-48.

Layman C.A., Araujo M.S, Boucek R., Hammerschlag-Peyer C.M., Harrison E., Jud Z.R., Matich P., Rosenblatt A.E., Vaudo J.J., Yeager L.A., Post D.M. and Bearhop S. 2012. Biol. Rev., 87, 545-562.

McCarthy J.M., Hein C., Olden J.D. and Vander Zanden M.J., 2006. Coupling long-term studies with meta-analysis to investigate impacts of non-native crayfish on zoobenthic communities. Freshw. Biol. , 51, 224-235.

McCutchan J.H. Jr, Lewis W.M., Kendall C. and McGrath C.C., 2003. Variation in trophic shift for stable isotope ratios of carbon, nitrogen, and suphur. Oikos, 102, 378-390.

Momot W.T. and Gowing H., 1972. Differential seasonal migration of the crayfish Orconectes virilis (Hagen), in Marl lakes. Ecology, 53, 479-483.

Montemarano J.J., Kershner M.W. and Leff L.G., 2007. Crayfish effects on fine particulate organic matter quality and quantity. Fund. Appl. Limnol., 169, 223-229. 
Nakano S. and Murakami M., 2001. Reciprocal subsidies: dynamic interdependence between terrestrial and aquatic food webs. Proc. Natl. Acad. Sci., 98, 166-170.

Parnell A.C., Inger R., Bearhop S. and Jackson A.L., 2010. Source Partitioning Using Stable Isotopes: Coping with Too Much Variation. PLoS ONE, 5, e9672.

Peterson B.J. and Fry B., 1987. Stable isotopes in ecosystem studies. Annu. Rev. Ecol. Syst., 18, 292-320.

Post D., 2002. Using stable isotopes to estimate trophic position: models, methods, and assumptions. Ecology, 83, 703-718.

Quevedo M., Svanbäck R. and Eklöv P, 2009. Intrapopulation niche partitioning in a generalist predator limits food web connectivity. Ecology, 90, 2263-2274.

R Development Core Team, 2009. R: A language and environment for statistical computing. R Foundation for Statistical Computing, Vienna, Austria. ISBN 3-900051-07-0, http://www.R-project. org.

Rodriguez C.F., Becares E., Fernandez-Alaez M. and Fernandez-Alaez C., 2005. Loss of diversity and degradation of wetlands as a result of introducing exotic crayfish. Biol. Inv., 7, 75-85.

Rubenstein D.R. and Hobson K.A., 2004. From birds to butterflies: animal movement patterns and stable isotopes. Trends Ecol. Evol., 19, 256-263.

Ruokonen T.J., Karjalainen J, Kiljunen, Pursiainen M. and Hämäläinen H., 2012. Do introduced crayfish affect benthic fish in stony littoral habitats of large boreal lakes? Biol. Inv., 14,813-825.

Schindler D.E. and Scheuerell M.D., 2002. Habitat coupling in lake ecosystems. Oikos, 98, 177-189.

Schofield K.A., Pringle C.M., Meyer J. L. and Sutherland A.B., 2001. The importance of crayfish in the breakdown of rhododendron leaf litter. Freshw. Biol., 46, 1191-1204.

Solomon C.T., Carpenter S.R., Clayton M.K., Cole J.J., Coloso J.J., Pace M.L., Vander Zanden M.J. and Weidel B.C., 2011. Terrestrial, benthic and pelagic resource use in lakes: results from a threeisotope Bayesian mixing model. Ecology, 92, 1115-1125.

Stendera S. and Johnson R.K., 2008. Habitat-specific stability and persistence of benthic invertebrate communities in boreal lakes. Fund. Appl. Limnol., 171, 311-322.

Stenroth P. and Nyström P., 2003. Exotic crayfish in a brown water stream: effects on juvenile trout, invertebrates and algae. Freshw. Biol., 48, 466-475.

Stenroth P., Holmqvist N., Nyström P., Berglund O., Larsson P. and Graneli W., 2006. Stable isotopes as an indicator of diet in omnivorous crayfish (Pacifastacus leniusculus): the influence of tissue, sample treatment, and season. Can. J. Fish. Aquat. Sci., 63, 821-831.

Suring E. and Wing S.R., 2009. Isotopic turnover rate and fractionation in multiple tissues of red rock lobster (Jasus edwardsii) and blue cod (Parapercis colias): Consequences for ecological studies. J. Exp. Mar. Biol. Ecol., 370, 56-63.

Syväranta J., Hämäläinen H. and Jones R.I., 2006. Within-lake variability in carbon and nitrogen stable isotope signatures. Freshw. Biol., 51, 1090-1102.

Usio N., 2000. Effects of crayfish on leaf processing and invertebrate colonisation of leaves in a headwater stream: decoupling of a trophic cascade. Oecologia, 124, 608-614.

Vadeboncoeur Y. and Vander Zanden M.J., 2002. Putting the lake back together: reintegrating benthic pathways into lake food web models. BioScience, 52, 44-54.

Vander Zanden M.J. and Graton C., 2011. Blowin' in the wind: reciprocal airborne carbon fluxes between lakes and land. Can. J. Fish. Aquat. Sci., 68, 170-182.

Vander Zanden M.J. and Rasmussen J.B., 2001. Variation in delta N-15 and delta C-13 trophic fractionation: Implications for aquatic food web studies. Limnol. Oceanog., 46, 2061-2066.

Vander Zanden M.J. and Vadeboncoeur Y., 2002. Fishes as integrators of benthic and pelagic food webs in lakes. Ecology, 83, 2152-2161.

Vander Zanden M.J., Casselman J.M. and Rasmussen J.B., 1999. Stable isotope evidence for the food web consequences of species invasions in lakes. Nature, 401, 464-467.

Vander Zanden M.J., Chandra S., Park S., Vadeboncoeur Y. and Goldman C.R., 2006. Efficiencies of benthic and pelagic trophic pathways in a subalpine lake. Can. J. Fish. Aquat. Sci., 63, 2608-2620.

Vanni M.J., 2002. Nutrient cycling by animals in freshwater ecosystems. Annu. Rev. Ecol. Syst., 33, 341-370.

Weidman R.P., Schindler D.W. and Vinebrooke R.D., 2011. Pelagic food web interactions among benthic invertebrates and trout in mountain lakes. Freshw. Biol., 6, 1081-1094.

Westman K., Savolainen R. and Julkunen M., 2002. Replacement of the native crayfish Astacus astacus by the introduced species Pacifastacus leniusculus in a small, enclosed Finnish lake: a 30-year study. Ecography, 25, 53-73. 